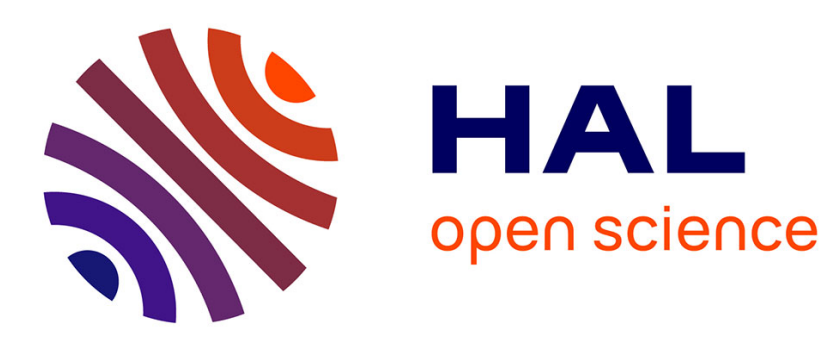

\title{
Effects of multiple Bt proteins and GNA lectin on in vitro-reared honey bee larvae
}

Harmen Hendriksma, Stephan Härtel, Dirk Babendreier, Werner Ohe, Ingolf Steffan-Dewenter

\section{- To cite this version:}

Harmen Hendriksma, Stephan Härtel, Dirk Babendreier, Werner Ohe, Ingolf Steffan-Dewenter. Effects of multiple Bt proteins and GNA lectin on in vitro-reared honey bee larvae. Apidologie, 2012, 43 (5), pp.549-560. 10.1007/s13592-012-0123-3 . hal-01003645

\section{HAL Id: hal-01003645 https://hal.science/hal-01003645}

Submitted on 1 Jan 2012

HAL is a multi-disciplinary open access archive for the deposit and dissemination of scientific research documents, whether they are published or not. The documents may come from teaching and research institutions in France or abroad, or from public or private research centers.
L'archive ouverte pluridisciplinaire HAL, est destinée au dépôt et à la diffusion de documents scientifiques de niveau recherche, publiés ou non, émanant des établissements d'enseignement et de recherche français ou étrangers, des laboratoires publics ou privés. 


\title{
Effects of multiple Bt proteins and GNA lectin on in vitro-reared honey bee larvae
}

\author{
Harmen P. HeNDRIKSMA ${ }^{1}$, Stephan HärTeL ${ }^{1}$, Dirk BABENDREIER ${ }^{2}$, \\ Werner von der $\mathrm{OHE}^{3}$, Ingolf StefFan-Dewenter ${ }^{1}$ \\ ${ }^{1}$ Department of Animal Ecology and Tropical Biology, Biocentre, University of Würzburg, Am Hubland, \\ 97074 Würzburg, Germany \\ ${ }^{2}$ CABI-Europe Switzerland, Rue des Grillons 1, 2800 Delèmont, Switzerland \\ ${ }^{3}$ Institut für Bienenkunde (Institute for Apidology), LAVES (Lower Saxony State Office for Consumer Protection \\ and Food Safety), Herzogin-Eleonore-Allee 5, 29221 Celle, Germany
}

Received 13 October 2011 - Revised 31 December 2011 - Accepted 17 January 2012

\begin{abstract}
The honey bee is a key non-target arthropod in environmental risk assessments of genetically modified crops. We analyzed for the first time combined effects of three Bt proteins conferring insect resistances, and a CP4protein conferring an herbicide resistance as simultaneously expressed in one GM maize. Furthermore, the biosafety of Galanthus nivalis agglutinin (GNA lectin), a candidate protein for pest control was tested. Under worst-case exposure scenario, by using controlled in vitro larvae rearing, the combination of Bt proteins showed no adverse effects on bee larvae. In contrast, the GNA lectin was toxic at a $144 \mathrm{~h} \mathrm{LD}_{50}$ of $16.3 \mu \mathrm{g} / \mathrm{larva}$. The prepupal weight was found to differ between the larvae collection days and between the colonies used for the experiment, explaining up to five times more data variance than the protein treatments ( $N=709$ prepupae). In conclusion, neither single nor a mix of different Bt proteins were found harmful to honey bee larvae.
\end{abstract}

Apis mellifera / Bacillus thuringiensis / environmental risk assessment / genetically modified crops / Cry protein

\section{INTRODUCTION}

The Western honey bee (Apis mellifera L.) is a main pollinator species of agricultural crops and wild plants worldwide (Klein et al., 2007; Potts et al., 2010). By feeding on pollen and nectar, honey bees can be exposed to insecticidal proteins expressed by genetically modified (GM) crops (Duan et al., 2008; Romeis et al., 2008;

Electronic supplementary material The online version of this article (doi:10.1007/s13592-012-0123-3) contains supplementary material, which is available to authorized users.

Corresponding author: H.P. Hendriksma, harmen-pieter.hendriksma@uni-wuerzburg.de Manuscript editor: Monique Gauthier
Malone and Burgess 2009). Transgenic gene products expressed in insect-resistant GM crops can confer protection against specific herbivorous pest insects. In particular, the expression of Cry proteins derived from the bacterium Bacillus thuringiensis (Bt) is increasing in commercially cultivated GM crops (James, 2010). Cry proteins typically affect the larvae of susceptible holometabolous insects by a lethal damage to the peritrophic membrane within the gut (De Maagd et al., 2001). Recent developments in crop biotechnology focus on multi-insect-resistant crops with high expression levels, producing a number of different insecticidal proteins at the same time (James, 2010). In general, the stacking of traits in one event aims to enhance the protection against target pest insects by causing additive or synergistic 
toxicity effects (Wolt, 2011). Target lepidopteran pest insects are reported to be synergistically affected by the different combinations of CrylAb, Cry1Ac, Cry1F and/or Cry2Ab2 (Lee et al., 1996; Stewart et al., 2001; Khasdan et al., 2007; Sharma et al., 2010).

Pollen is the main protein source for honey bees. A colony can accumulate up to $55 \mathrm{~kg}$ of pollen per year (Seeley, 1985), and nurse bees consume 3.4 to $4.3 \mathrm{mg}$ of pollen per day (Crailsheim et al., 1992). Most of the pollen is used to produce food for the larvae in their hypopharyngeal gland, but it was shown that nurse bees do not pass $\mathrm{Bt}$ proteins on to larvae via their food secretions (Babendreier et al., 2005). Thus, the exposure of Bt protein to larvae is limited to direct pollen feeding, which was found to be about $2.0 \mathrm{mg}$ for maize pollen per larva during their development time (Babendreier et al., 2004). It thus appears that exposure of larvae towards transgenic products is lower than for adult bees. However, larval stages generally show a higher susceptibility to Bt proteins than adults, with neonate larvae being more sensitive than older larval instars (Glare and O'Callaghan 2000; Yao et al., 2008). Hence, we follow the idea of testing the potentially most sensitive life history stage for $\mathrm{Bt}$ proteins (Romeis et al., 2011), i.e., honey bee larvae.

Bt crops expressing single Cry proteins were not found to impact honey bees during a recent meta-analysis (Duan et al., 2008). However, no studies assessing the risk of simultaneously expressed Cry proteins on honey bees have been conducted until now. To assess the biosafety of pollen-rewarding transgenic crops with multi-insect resistances, the protein expression of a stacked Bt maize variety "Mon89034× Mon88017" was taken as a reference model. Combined effects of four transgenic proteins were tested individually, and in combinations that are proportional to the expression levels in stacked Bt pollen: Cry1A.105, Cry2Ab2, $\mathrm{Cry} 3 \mathrm{Bb} 1$ against major lepidopteran and coleopteran pest insects and the CP4 EPSPS protein conferring herbicide resistance. The arthropodactive protein lectin (Babendreier et al., 2008; Jaber et al., 2010) was also tested for toxic effects on honey bees since it is a future pest control candidate for expression in, e.g., maize and rapeseed.

We used a concentration gradient which exceeds the estimated environmental concentration (EEC) by a multifold, and performed experiments that took into account protein interactions, the colony background of test individuals, thereby effectively monitoring honey bee biosafety.

\section{MATERIAL AND METHODS}

\subsection{In vitro larvae bioassay}

The rearing of larvae was performed under controlled laboratory conditions following the methods of Aupinel et al. (2007) and Hendriksma et al. (2011a) (Supplement P). These methods were adopted to test for the first time effects of mixed transgenic proteins on in vitro-reared larvae. The test larvae originated from six donor honey bee colonies with naturally mated non-sibling queens (A. mellifera carnica). On June 23 and 25, 2009, queens were trapped on artificial combs within their colonies (Cupularve, Nicoplast $($, Maisod, France). We further refer to the material and methods section in Hendriksma et al. (2011a), for the first-instar larvae collection (D4; age mean 10:29 hours) and the details of in vitro rearing (D5-D9).

The larvae finished their in vitro diet at day 10 and actively stopped digestion by a molt and defecation of the intestinal tract, which terminated the exposure to ingested products. By day 11, the larvae were stretched and passive, which is indicative for the prepupae phase. To assess lethal effects, the survival of larvae was noted daily, and moribund larvae were removed, as recognized by occasional black or white sub-dermal necrotic stains or a visible loss of turgor. Potential sublethal effects were monitored on day 11 , by weighing each prepupa on an analytical microbalance to the nearest $0.001 \mathrm{~g}$ (Hendriksma et al., 2011a).

To reflect transgenic protein exposure by GM pollen consumption, eight treatments were established by mixing different proteins into the semiartificial diet of second-instar larvae on day 5. The diet was ingested by the larvae during the subsequent days. All protein treatments were made up to account 
for a concentration gradient (Table I). The bioassay was conducted with larvae, which were sampled on two successive days ( $N=755$ larvae). Considering the different colony backgrounds, the larvae were equally distributed over the concentration gradient within each treatment, with mean 18 replicate larvae per individual treatment dose.

\subsection{Protein treatments}

The Bt protein resistances by Cry1A.105 and Cry2Ab2 target a wide range of common lepidopteran pests (e.g. armyworms Spodoptera sp., black cutworm Agrotis ipsilon, corn borers, e.g., Ostrinia nubilalis and corn earworms, e.g., Helicoverpa zea). $\mathrm{Cry} 3 \mathrm{Bb} 1$ confers resistance against coleopteran pests like the western, northern, and Mexican corn rootworms Diabrotica spp. (Coleoptera: Chrysomelidae). A non-insect-related protein EPSPS of Agrobacterium sp. strain $\mathrm{CP} 4$ was tested as transgenic protein conferring resistance to glyphosate, the active ingredient of the herbicide Roundup.

For each protein, a stock diet was made with a maximum treatment dose, of which an exponential concentration gradient was made by repetitively diluting each stock solution with basic diet with the factor $1 /$ 10. All the diets were made on the first day of larval collection, stored at $6^{\circ} \mathrm{C}$, and warmed up to $35^{\circ} \mathrm{C}$ before application. The stock diets with the transgenic proteins were made by a replacement of the water fraction in the diet with buffer solutions containing the purified transgenic proteins (obtained from Monsanto company, St. Louis, USA and stored at $-80^{\circ} \mathrm{C}$ preceding application). The transgenic protein stock diet contained per $10 \mu \mathrm{L}: 3.2 \mu \mathrm{g}$ Cry1A.105 [treatment 1], $0.124 \mu \mathrm{g}$ Cry2Ab2.820 [2], $3.0 \mu \mathrm{g}$ Cry3Bb1 [3], $6.4 \mu \mathrm{g}$ CP4 EPSPS [4] or $7.03 \mu \mathrm{g}$ Cry1, Cry2, Cry3, and CP4 in the proportion as in $2 \mathrm{mg}$ Mon $89034 \times$ Mon 88017 pollen [5] (Monsanto Company, 2009). At the volumetric maximum, treatments $[1,2,3]$ exceeded an environmental exposure concentration (EEC) of $2 \mathrm{mg}$ pollen by 186 times, and the treatments $[4,5]$ by 18.6 times (Technical Dossier \{Part I\} of the summary \{Part II $\}$ of Monsanto Company, 2009; Table I). The Lepidoptera active Cry proteins were verified on toxicity (Aglais urticae; pers. comm. Schuppener, RWTH Aachen).

Buffer chemicals may cause effects on larvae as well, thus zero concentration controls for transgenic protein treatments were diets with buffer solution [B1/ B2/B3/B4/Bmix] (Table I). The mixed buffer treatment [6] is the direct control of the stacked protein treatment [5], containing the identically proportioned buffer mix. Bovine serum albumin (BSA) was applied as a noninsecticidal protein control [7]: maximally $8 \%$ solid protein $(w / w)$. Additionally, snowdrop lectin (GNA; Galanthus nivalis L. agglutinin) was used as another class of transgenic pest control proteins [8] (Romeis et al., 2003; Babendreier et al., 2008) at maximally $0.8 \%$ $(w / w)$ solid protein (Table I). The buffer chemicals and the two control proteins were ordered at SigmaAldrich Chemie Gmbh, Munich, Germany.

\subsection{Statistics}

Four variables of possible influence on the data were considered: eight treatments, one gradient, six colonies, and two trials (larval sampling days). The concentration gradient with the dosage levels $d \times 10^{-\infty}, 10^{0}, 10^{1}, 10^{2}$, $10^{3}, 10^{4}$ was $\log$ transformed into the progressive values $0,1,2,3,4,5$ to correct for the exponential progression. This allowed testing gradient as a standardized continuous linear variable, since treatment doses [treatments 1-6] were all in proportion to each other, reflecting the transgenic protein concentrations within stacked Bt pollen. Larval survival and prepupae weight were the tested response variables; the dose-response tests were performed by regression over the concentration gradient. By the use of the interaction term treatment $\times$ gradient, treatment-specific dose-response effects could be compared. All variables and all meaningful interactions were tested and successively rejected from the models when they were insignificant $(\alpha=0.05)$. For all post hoc tests, such as in the comparison of one treatment with seven other treatments, the significance of $P$ values was determined at $\alpha=0.05$, applying Bonferroni corrections on the $P$ values for the number of comparisons.

The survival of larvae was analyzed with proportional hazards regression models (Coxph: Cox and Oakes 1990; Fox 2002) using the open-source statistic software R, version 2.11.1 (R Development Core Team, 2010). This regression on survival dynamics over time can take multiple explanatory variables into account, and has the option to include a random factor to correct for non-independence within the dataset (Zuur et al., 2009; Hendriksma et al., 2011a) (Table IIA). In case of 


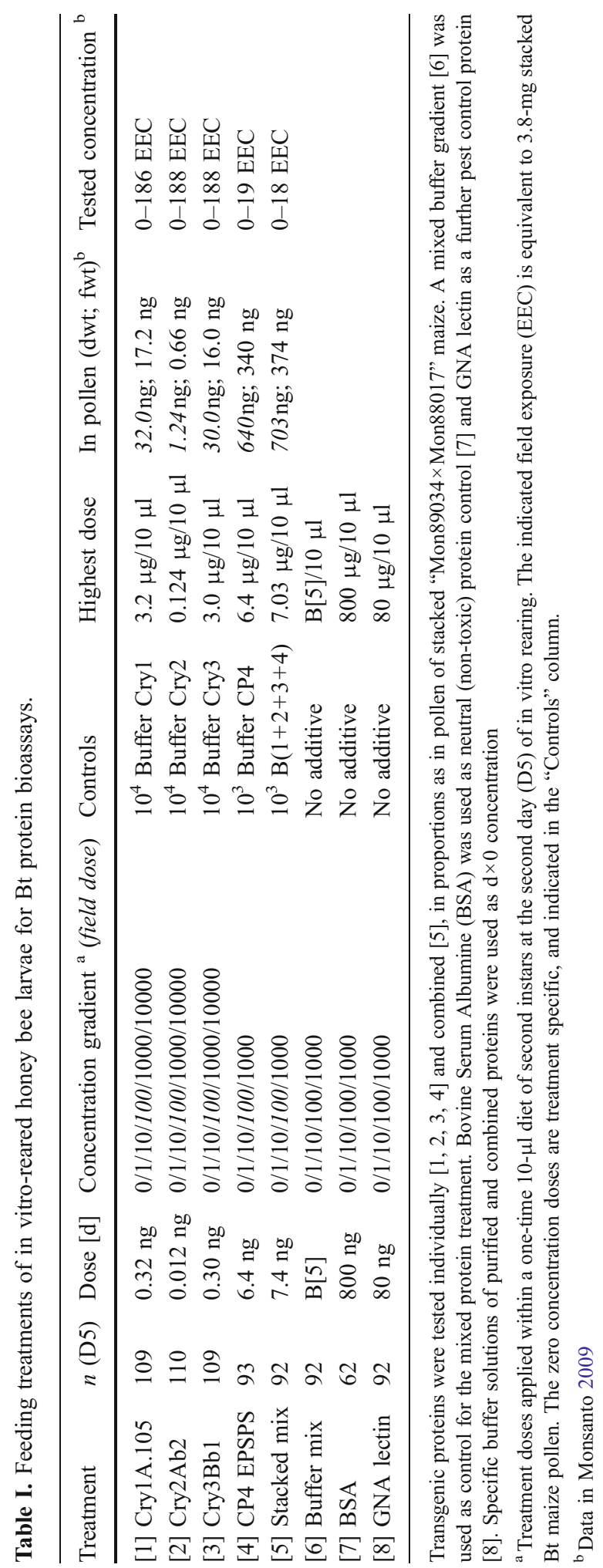


Table II. Summary statistics of protein treatments, gradient, colony origin, and trials on (A) mortality rates of in vitro-reared honey bee larvae $\left(R^{2} \leq 0.55 ; \mathrm{n}=755\right)$ and (B) weight of prepupae $\left(R^{2}=0.081 ; \mathrm{n}=709\right)$.

\begin{tabular}{|c|c|c|c|c|c|c|c|}
\hline \multicolumn{2}{|c|}{ Explanatory variables (models A and B) } & \multirow{2}{*}{$\frac{d . f .}{7}$} & \multirow{2}{*}{$\frac{\chi^{2}}{57.5}$} & \multirow[t]{2}{*}{$S S(78,626)$} & \multirow[t]{2}{*}{$R^{2}$} & \multirow[t]{2}{*}{$F$ value } & \multirow{2}{*}{$\frac{P \text { value }}{<0.001^{* * * *}}$} \\
\hline A & Treatment & & & & & & \\
\hline & Gradient (as linear variable) & 1 & 16.2 & & & & $<0.001 * * *$ \\
\hline & Treatment/gradient & 6 & 60.9 & & & & $<0.001 * * *$ \\
\hline & Colony (as random factor) & 1 & 4.10 & & & & \\
\hline \multirow[t]{6}{*}{ B } & Treatment & 7 & & 530 & 0.007 & 0.71 & 0.66 \\
\hline & Colony & 5 & & 1,966 & 0.025 & 3.70 & $0.003 * *$ \\
\hline & Trial & 1 & & 795 & 0.010 & 7.48 & $0.006^{* *}$ \\
\hline & Gradient (as linear variable) & 1 & & 325 & 0.004 & 3.06 & 0.081 \\
\hline & Treatment/gradient & 7 & & 2,054 & 0.026 & 2.76 & $0.008^{* *}$ \\
\hline & Residuals & 687 & & 72,956 & 0.928 & & \\
\hline
\end{tabular}

$P$ value significances are based on an $\alpha$-level of 0.05

$* * P<0.01, * * * P<0.001$

toxicity, $\mathrm{LD}_{50}$ values were calculated, taking into account the colony dependence of test individuals (Hendriksma et al., 2011a), with 95\% confidence intervals determined by Fieller's method (Finney, 1971; Niu et al., 2011). The prepupae weight analysis was performed using linear models (lm: Chambers, 1992, Anova type III) to measure treatment, colony, gradient, and trial effects (Table IIB).

\section{RESULTS}

\subsection{Survival rates}

The three tested Bt proteins Cry1A.105 $(n=$ $109)$, Cry2Ab2 $(n=110)$, Cry3Bb1 $(n=109)$ [treatments 1-3] did not show insecticidal effects on developing honey bee larvae, with survival rates between $95.5 \%$ and $100 \%$ per test gradient (Table III). Even at the highest test concentration, 186 times exceeding the EEC, no susceptibility to any of the three $\mathrm{Bt}$ proteins was found (survival 100\% [1], 94.4\% [2], 100\% [3]). Similarly, for the CP4 protein treatment ([4] $92.5 \%, n=93$ ), and the combination of all four transgenic proteins containing all three $\mathrm{Bt}$ proteins ([5] 97.8\%, $n=92$ ) the survival was high, and remained unaffected even at the highest concentration tested (Figure 1).
The buffer mix [6] with $96.6 \%$ survival was not significantly different from the five transgenic protein treatments $\left(\chi^{2} \leq 5.0, P\right.$ value $\geq$ 0.18 ). With mean mortality rates of $\leq 7.5 \%$, no treatment-specific dose-response effects were found within the tested groups [1-7] $\left(\chi^{2} \leq 1.17\right.$, $P$ value $\geq 0.19$, Table III).

In contrast, GNA lectin [8] showed a significant increase in larval mortality over the concentration gradient (Supplement S: $R^{2}=0.52, \chi^{2}=67.0, P<$ $0.001, n=93)$. GNA lectin [8] killed all test larvae at the highest dose of $5 \% \mathrm{w} / w\left(\mathrm{LT}_{100}=144 \mathrm{~h} ; n=\right.$ 20; Figure 1). The 96 and $144 \mathrm{~h} \mathrm{LD}_{50}$ values were indicated 39.1 and $16.7 \mu \mathrm{g}$ dietary lectin protein per larva respectively (with 95\% CI's 30.4-51.9 and 13.5-20.8 $\mu \mathrm{g}$ /larva, respectively). A post hoc test over all treatments, and an additional test on the highest applied doses only (Figure 1), confirmed that lectin was the only treatment causing mortality (Table III). It is important to note that the experiment had a low residual background mortality of mean $3.5 \%$ (26/735 larvae; excluding the highest dose of the lectin treatment).

Neither the colony background of test organisms $\left(\chi^{2}=3.59\right.$, d.f. $\left.=5, P=0.61\right)$ and their potential interaction with treatments $\left(\chi^{2}=37.0\right.$, d.f. $=35, P=0.38)$, nor the two trials $\left(\chi^{2}=0.70\right.$, d.f. $=1, P=0.40)$ were found to affect survival of honey bee larvae. Only the treatment $\times$ gradient 
Table III. Mortality of 755 in vitro-reared honey bee larvae.

\begin{tabular}{|c|c|c|c|c|c|c|c|c|c|c|c|}
\hline Treatment & $\mathrm{d}^{*}$ & 0 & 1 & 10 & 100 & 1000 & 10000 & Total mortality & Gradient & $R^{2}$ & $P$-value \\
\hline [1] Cry1A.105 & & $0 \%$ & $0 \%$ & $0 \%$ & $0 \%$ & $0 \%$ & $0 \%$ & $0 \%(0 / 109)$ & $\chi^{2}=0$ & 0 & 1 \\
\hline [2] Cry2Ab2 & & $5.00 \%$ & $0 \%$ & $5.60 \%$ & $5.60 \%$ & $5.60 \%$ & $5.60 \%$ & $4.5 \%(5 / 110)$ & $\chi^{2}=0.21$ & 0.040 & 0.64 \\
\hline [3] Cry3Bb1 & & $5.30 \%$ & $5.30 \%$ & $0 \%$ & $0 \%$ & $0 \%$ & $0 \%$ & $1.8 \%(2 / 109)$ & $\chi^{2}=1.71$ & 0.089 & 0.19 \\
\hline [4] CP4 epsps & & $5.00 \%$ & $16.70 \%$ & $11.10 \%$ & $5.30 \%$ & $0 \%$ & & $7.5 \%(7 / 93)$ & $\chi^{2}=1.14$ & 0.115 & 0.29 \\
\hline [5] Stacked MIX & & $0 \%$ & $5.30 \%$ & $0 \%$ & $5.60 \%$ & $0 \%$ & & $2.2 \%(2 / 92)$ & $\chi^{2}=0.00$ & 0.041 & 0.97 \\
\hline [6] BUFMIX & & $0 \%$ & $0 \%$ & $11.10 \%$ & $5.60 \%$ & $0 \%$ & & $3.4 \%(3 / 88)$ & $\chi^{2}=0.23$ & 0.070 & 0.63 \\
\hline [7] BSA & & $7.70 \%$ & $8.30 \%$ & $8.30 \%$ & $0 \%$ & $8.30 \%$ & & $6.6 \%(4 / 61)$ & $\chi^{2}=0.08$ & 0.090 & 0.78 \\
\hline [8] GNA-Lectin & & $6.70 \%$ & $0 \%$ & $4.80 \%$ & $5.30 \%$ & $100 \%$ & & $24.5 \%(23 / 94)$ & $\chi^{2}=27.6$ & 0.524 & $<0.001 * * *$ \\
\hline
\end{tabular}

Second-instar larvae were exposed to a protein dose within their diet (D5) and monitored for survival of test individuals up to the prepupae stage where larvae finish eating and growing (D11). The tabulated statistics for the gradient were based on individual treatment subsets. Color coding is used to visualize potential patterns in mortality (white $0 \%$, light gray $<10 \%$, dark gray $>10 \%$, black $100 \%$ mortality)

$P$ value significances are based on an $\alpha$-level of 0.05

$* * * P<0.001$

interaction was found to be significant, driven by lectin [8] as sole discriminate treatment (post hoc $P$ values $<0.001$; Supplement $\mathrm{S}$ ).

\subsection{Prepupae weights}

The mean prepupal weight was in range of 138.9 to $143.6 \mathrm{mg}$ (Supplementary Table S), showing no differences between treatments $(P=$ 0.66; Table IIB). The applied factor gradient did not affect prepupal weight ( $P=0.08$; Table II B), showing the absence of dose-related effects within treatments (Figure 2; post hoc $P>0.13$ ). However, between treatments dose-response differences were present ( $P=0.008$; Table IIB), with $\mathrm{CP} 4$ [4] and the protein mix [5] showing contrasting responses in comparison to Cry2 [2], (Figure 2, post hoc $P$ values $<0.012$, Supplement $W$ ). We like to point out that neither the buffer control [6] nor the BSA control protein were different from the single $\mathrm{Bt}$, or mixed transgenic protein treatments [1-5]. The 1.5-mg difference in prepupal weight between the larvae collection days was found significant $(P=0.006$; Table IIB). Similarly, a colony effect was found statistically significant ( $P=0.002$; Table IIB), with a mean weight differences of 3.8 to $4.6 \mathrm{mg}$ between colonies (post hoc $P$ values $<0.029$, Supplement W).
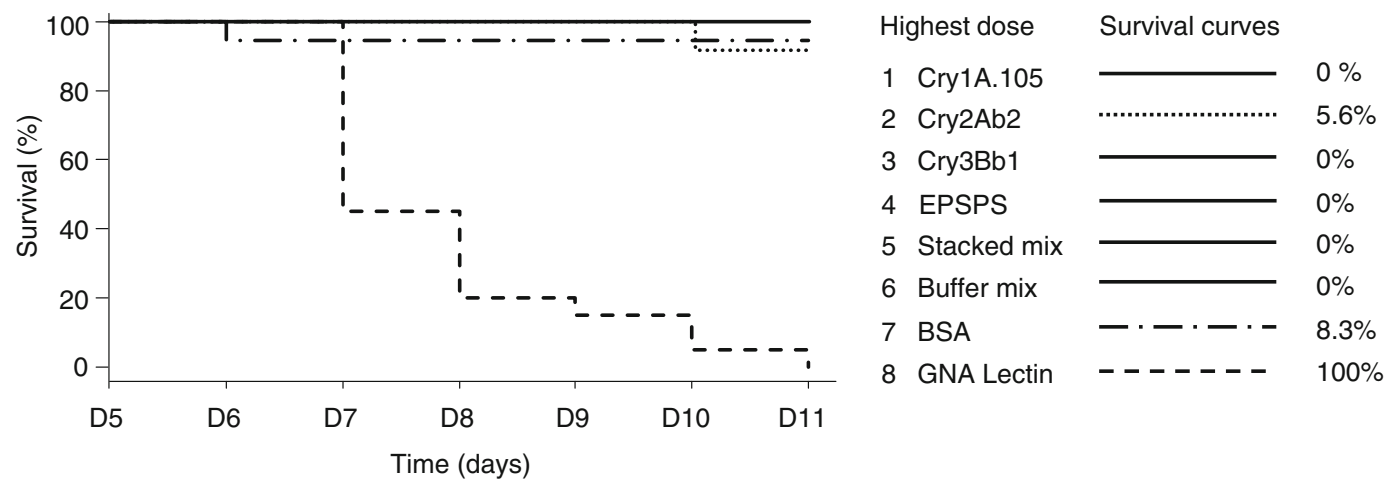

Figure 1. Survival of in vitro-reared honey bee larvae following treatments on day 5 (D5) with the highest protein concentrations tested: [1] $3.2 \mu \mathrm{g}$ Cry1A.105, [2] $0.124 \mu \mathrm{g}$ Cry2Ab2, [3] $3.0 \mu \mathrm{g}$ Cry3Bb1, [4] $6.4 \mu \mathrm{g}$ CP4 EPSPS, [5] $6.8 \mu \mathrm{g}$ stacked mix, [6] buffer mix, [7] $800 \mu \mathrm{g}$ BSA, [8] $80 \mu \mathrm{g}$ GNA lectin. 


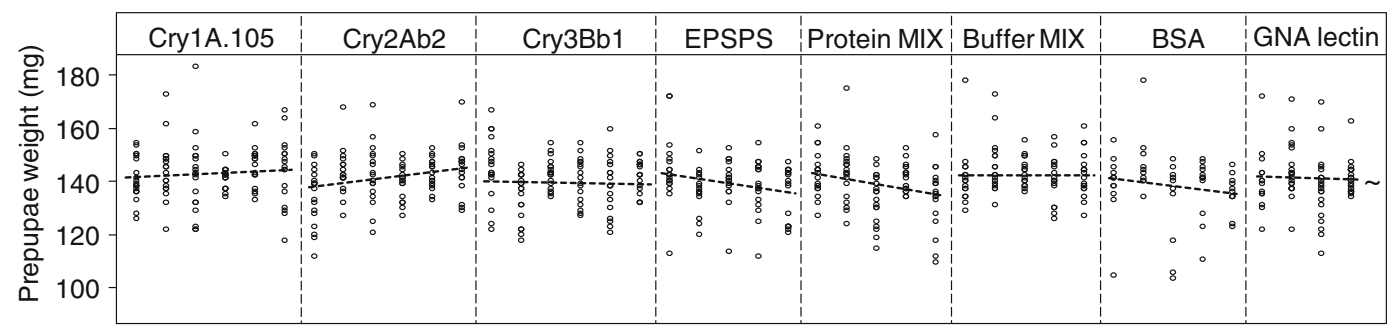

Treatment gradients $\left(d^{*} 0 / 1 / 10 / 100 / 1000 / 10000\right)$

Figure 2. Prepupal weight of protein exposed larvae $(n=709)$. Dose-response effects of transgenic proteins on the prepupae weight of in vitro-reared honey bee worker larvae are shown. Dotted lines indicate non-significant dose-response result for each treatment at increasing concentrations (for treatment details see Table I and for statistics Tables IIB and IV). Note that at the highest lectin concentration, all test individuals had died (tilde).

Within the prepupae weight data, no explanatory variable, nor any interaction between variables, substantially contributed to the explanation of variance $\left(R^{2} \leq 0.026\right.$, Table IIB). Finally, a low weight of prepupae was not found to correlate with a higher larval mortality rate $\left(F_{(1,40)}=0.16, P=0.69 ; R^{2}=0.004\right)$.

\section{DISCUSSION}

\subsection{Toxicity of Cry proteins and CP4}

The cultivation of GM crops with insect resistances requires comprehensive biosafety assessments, with robust and highly standardized bioassays for main non-target organisms. We used a sensitive and well suited in vitro larvae-rearing method to study single and multiple insect-resistant Bt crop effects on the main pollinator $A$. mellifera. The three tested purified Bt proteins, expressed in the pollen of the reference maize variety "Mon $89034 \times$ Mon88017" did not affect survival rates and weight gain of second-instar larvae, even at $\mathrm{Bt}$ toxin amounts exceeding a normal $2 \mathrm{mg} \mathrm{Bt}$ maize pollen EEC by 186 times. Thus, stacking of three Bt toxins showed no lethal or sublethal effects on honey bee larvae. Nonetheless, unknown subtle Bt effects may have remained unrevealed by this study.

Our tested Cry1A.105 toxin is a "chimeric" protein, developed by recombining $c r y l A c$, $c r y l F$, and $c r y l A b$ genes of different $B$. thur- ingiensis strains. Compared to the native proteins, chimeric proteins are designed to have an increased toxicity and have a broadened range of target pest insects (Pardo-López et al., 2009; Pigott et al., 2008). Regulatory agencies may omit additional biosafety tests on chimeric proteins, if and when the predecessor proteins were assessed to be safe. However, as reduced selectivity and increased toxicity may not only affect target insects but also non-target insects, extrapolating risks of novel chimeric proteins based only on the data of the predecessor proteins could be misleading. Nevertheless, our data show that this chimeric Cry1A.105 protein is not directly harmful to $A$. mellifera larvae.

Recently conducted pollen feeding trials, in which in vitro-reared third-instar larvae were exposed to $2 \mathrm{mg}$ pollen of the Bt maize variety "Mon89034×Mon88017" during 5 days, showed 100\% survival (Hendriksma et al., $2011 \mathrm{~b}$ ) and thus are fully in line with results from worst-case exposure scenarios obtained in the present study. Similarly, the overall mean weight of prepupae and also mean prepupal weight at the highest applied purified protein doses are in perfect range with the pollen feeding test (Hendriksma et al., 2011b). Our results on single $\mathrm{Bt}$ proteins further complement the less standardized colony level studies on single Cry1 Ab or Cry $1 \mathrm{~F}$ maize pollen (Hanley et al., 2003) and the purified Cry3B protein (Arpaia, 1996), for which also no deleterious effect by Cry protein were found on honey bee 
brood. A recent in vitro study on the effect of purified Bt protein Cry1 Ac $(50 \mu \mathrm{g})$ on Africanized honey bees reported no effect on larval survival rates, development time, or adult body mass (Lima et al., 2011). Together with our results on Cry1A.105 and earlier studies, a high Cry1 protein safety range for $A$. mellifera larvae can be confirmed. While numerous studies have been conducted on Cry1 Bt toxins, few studies have been done on Cry3 Bt toxins and hardly any on potential risks of Cry2 $\mathrm{Bt}$ toxins on bees (Malone and Burgess, 2009). Thus our results add valuable information here.

Similar to the results obtained for single Bt proteins, the transgenic mix of proteins as expressed in Bt pollen [5] did not affect larval survival or prepupal weight, not even at the highest concentration doses applied. Two observed dose-response differences, with CP4 [4] and the protein mix [5] showing contrasting responses in comparison to Cry2 [2], were not substantiated by individually significant doseresponse effects. In addition, the biological nontoxicity of all applied transgenic treatment concentrations has been underlined by very low explanatory values $(\leq 2.6 \%$; Table IIB), and the fact that the protein treatments [1-5] did never differ from the buffer control [6], or BSA [7] as non-toxic control. We conclude that the observed treatment differences were biologically irrelevant.

In general, the stacking of traits in one event aims to enhance the protection against target pest insects by causing additive or synergistic toxicity effects (Wolt, 2011). The uptake, transportation or degradation pathways within organisms are commonly involved at toxicant synergies (Andersen and Dennison, 2004). This typically addresses the mode of action of $\mathrm{Bt}$ proteins, disrupting the intestinal systems of target arthropods. Target pest insects are reported to be synergistically affected by combinations between Cry1Ab, Cry1Ac, Cry1F and/or Cry2Ab2 (Lee et al., 1996; Stewart et al., 2001; Khasdan et al., 2007; Sharma et al., 2010). If susceptible to Bt proteins, even to a small extent, non-target organisms need consideration on synergistic toxicity issues. However, the data presented here do not support any susceptibility of honey bee larvae to any of the three Cry toxins tested. Consequently, in our case study on mixed Bt effects on bees, additional mixed toxicity evaluations were regarded as irrelevant (e.g. testing on additivity of effects, or on synergistic or antagonistic effects). Our findings corroborate recent statements from EFSA that interactions among Cry1A.105, Cry2Ab2, Cry3Bb1, and CP4 EPSPS are unlikely, based on the known function and mode of action of these proteins (EFSA, 2010).

New to honey bee risk assessment is the testing of a purified transgenic CP4 EPSPS protein, both singly and mixed with the three $\mathrm{Bt}$ toxins like it would appear in the transgenic maize event. The Agrobacterium sp. strain CP4derived EPSP synthase is tolerant to the herbicide glyphosate (Padgette et al., 1995). Because it replaces the intolerant synthase, CP4 EPSPS enables continuation of amino acid biosynthesis after glyphosate herbicide treatment of plants (Steinrücken and Amrhein, 1980). Neither a mechanism, nor evidence exists that the CP4 EPSPS protein is harmful to animals, plants, or other life forms (Peterson and Shama, 2005). Our results further indicate that the CP4 protein does not pose a risk to pollinating insects when it is expressed in pollen of transgenic plants.

A number of $\mathrm{Bt}$ crops are assessed safe for A. mellifera, apparently due to missing receptors for the respective Bt toxins (Duan et al., 2008; Malone and Burgess, 2009). Even a hymenopteran-active Bt strain (PS86Q3; active to sawflies Diprion pini and Pristiphora abietin) was not found to affect honey bee larvae (Porcar et al., 2008). Nevertheless, a case by case risk assessment on future Bt crops is mandatory, since $\mathrm{Bt}$ products yet to be developed may pose new risks to bees (Romeis et al., 2006).

\subsection{Lectins}

In contrast to all other treatments, snowdropderived lectin (GNA) elicited mortality of all 
larvae at the highest concentration level $(0.8 \%$ $w / w$ in $10 \mu \mathrm{L}$ diet, $0.08 \mathrm{mg}$ per larva). This could be relevant for honey bees because GNA is regarded as a candidate for expression in transgenic crops like maize and rapeseed to confer resistance against pest insects (e.g. Romeis et al., 2003; Lehrman, 2007; Babendreier et al., 2008). In comparison, $1.0 \%$ GNA mixed into sucrose solution fed to the parasitic Hymenopterans Aphidius colemani, Trichogramma brassicae, and Cotesia glomerata, also reduced the survival of test individuals by $58 \%, 39 \%$, and $56 \%$, respectively (Romeis et al., 2003).

A dietary pollen feeding test $(1.5 \%, w / w)$ expressing transgenic pea lectin up to $1.2 \%$ of total soluble protein in oilseed rape pollen, revealed no negative effect on honey bee larvae (Lehrman, 2007), which is likely due to the relative low quantity of protein exposed. At the dose of $0.08 \%$ GNA in the diet, we found no lethal effects and also no indication of a sublethal inhibition of larval feeding. This result contrasts to mason bee larvae Osmia bicornis, which showed an inhibited food intake and had a reduced survival at $0.1 \%$ GNA in the diet (Konrad et al., 2008). Similarly, $0.1 \%$ GNA mixed into sucrose solution and fed to bumblebee Bombus terrestris workers and drones also showed reduced survival rates (Babendreier et al., 2008). A similar lectin (wheat germ agglutinin; WGA) was described affecting adult honey bee midgut esterase and protease activity at $0.1 \%$ WGA feeding (Belzunces et al., 1994).

An explanation for not finding sublethal effect at $0.08 \%(8 \mu \mathrm{g} / 10 \mu \mathrm{L})$ is that abovementioned studies fed the concentration constantly, while in the present study the honey bee larvae were exposed to it in one dietary application. In this case, an assumption of chronic exposure would better fit our data to the other mentioned studies; No effects at $0.005 \%$ [ $8 \mu \mathrm{g}$ GNA/total $160 \mu \mathrm{L}$ diet], and all individuals dead at $0.05 \%$ [80 $\mu \mathrm{g}$ GNA/160 $\mu \mathrm{L}]$.

In general, for potential GM crops expressing lectins, the risk will depend very much on the exposure levels (Babendreier et al., 2008; Malone and Burgess, 2009). Despite the fact that lectin-expressing GM crops are not commercialized, bees may already be exposed to lectins (Babendreier et al., 2008). Leek (Allium porrum) nectar can contain $0.02 \%$ of a mannose-binding lectin, similar to GNA (Peumans et al., 1997). As this concentration lies close to the effect range of about $0.1 \%$ as recorded in the above-mentioned studies, a potential insecticidal risk is not excluded. Thus, risks of transgenic plants expressing lectins for honey bees need to be addressed for all melliferous, as well as all polleniferous crops.

Table IV. Prepupal weight effects over the gradients, per treatment.

\begin{tabular}{llllllllllll}
\hline Proteins & $\mathrm{n}$ & Weight $(\mathrm{mg}) \pm \mathrm{SD}$ & $\mathrm{d} * 0$ & 1 & 10 & 100 & 1000 & 10000 & $R^{2}$ & $\mathrm{t}$-value & $P$-value \\
\hline [1] Cry1A.105 & 109 & $143.6 \pm 10.0$ & 141.7 & 144.8 & 142.6 & 142.1 & 146.1 & 144.6 & 0.008 & 0.92 & 1.0 \\
[2] Cry2Ab2 & 110 & $142.0 \pm 9.3$ & 135.7 & 143.9 & 143.3 & 140.4 & 143.7 & 145.4 & 0.184 & 2.25 & 0.20 \\
[3] Cry3Bb1 & 109 & $140.6 \pm 11.3$ & 145.6 & 135.1 & 143.8 & 137.4 & 139.1 & 142.6 & 0.088 & -0.44 & 1.0 \\
[4] CP4 Epsps & 93 & $139.8 \pm 10.3$ & 145.1 & 137.4 & 140.9 & 139.2 & 136.1 & & 0.059 & -2.23 & 0.21 \\
[5] Stacked mix & 92 & $139.5 \pm 10.2$ & 143.3 & 143.4 & 134.5 & 142.2 & 134.7 & & 0.068 & -2.42 & 0.13 \\
[6] Buffer mix & 92 & $142.9 \pm 10.8$ & 142.3 & 143.1 & 144.4 & 141.5 & 143.3 & & 0.000 & -0.01 & 1.0 \\
[7] BSA & 62 & $138.9 \pm 12.4$ & 139.6 & 147.6 & 132.6 & 138.6 & 136.5 & & 0.138 & -1.75 & 0.65 \\
[8] GNA Lectin & 92 & $141.6 \pm 10.7$ & 141.2 & 144.8 & 138.1 & 142.6 & $\dagger$ & & 0.001 & -0.35 & 1.0 \\
\hline
\end{tabular}

The overall mean weight per treatment is given (with the standard deviation). Indicated in the matrix are mean prepupae weights per treatment dose. The gradient follows the exponentially increasing low dose " $d$ ". The range of effects per treatment is indicated with a light gray shade for minima values and a dark gray shade for the maxima values. Symbol " $\uparrow$ " indicates that all test individual have died (at the highest level of lectin) for which no data on the weight of prepupae available 


\subsection{Methodological strength}

In comparison to the reported $19 \%$ background mortality at testing Cry1 Ab over the arval phase by Lima et al. (2011), the $0 \%$ mortality for Cry1A.105 fed larvae $(n=105)$, and a $3.5 \%$ general background mortality is a notable improvement for environmental risk assessment studies. The low mortality rate is linked to the non-grafting approach where minimizing contact with the larvae allows to optimize rearing success (Supplement P; Hendriksma et al., 2011a).

We started the Bt protein applications at the second-instar stage to reflect the natural exposure pathways in honey bees. This includes a safety margin, since exposure for young larvae is negligible because pollen are only in the larval food from the third-instar stage onwards (Simpson 1955, Jung-Hoffmann 1966) and Bt protein is not secreted via nurse bee feeding glands (Babendreier et al., 2005). Hive experiments reported similar weights of prepupae but revealed higher weight ranges (Babendreier et al., 2004). They found mean weights of 132 to $155 \mathrm{mg}$ for fully grown larvae $(\Delta 23.0 \mathrm{mg})$, also with a significant difference among colony backgrounds. This proves the in vitro bioassay to produce data in a representative range, with all level means in the range of the empirical data (Table IV).

The general question of whether laboratory studies on transgenic insecticidal crops can be extrapolated to the field situation has been recently addressed by Duan et al. (2010). They showed that indeed laboratory studies on GM crops show effects that are either consistent with, or more conservative than, those found in field studies, provided that ecologically relevant routes of exposure have been addressed properly. Since we here have included a wide range of concentrations including worst-case scenarios, it is concluded that our results are likely conservative, leaving a safety margin.

\section{CONCLUSIONS}

Under worst-case exposure scenarios, Bt proteins Cry1, Cry2, and Cry3 and the CP4- protein were not found to be toxic to developing honey bee larvae, and mixed toxicity effects were not indicated. The results presented in our case study on developing honey bee larvae extend the biosafety of single $\mathrm{Bt}$ proteins to multiple $\mathrm{Bt}$ proteins. In contrast, GNA lectin caused acute mortality among larvae, stressing the risk for beneficial insect pollinators in the agricultural landscape when GNA would be expressed in melliferous and/or polleniferous GM crops.

\section{ACKNOWLEDGEMENTS}

This is publication No. 1 produced within the project Assessing and Monitoring the Impacts of Genetically Modified Plants on Agro-ecosystems (AMIGA), funded by the European Commission in the Framework programme 7. THEME [KBBE.2011.3.5-01]. This study was also funded by the German Federal Ministry of Education and Research (Bundesministerium für Bildung und Forschung BMBF, project 0315215E). The experiments were performed at the Universities of Bayreuth and Würzburg (Bavaria).

Effets de plusieurs protéines Bt et de la lectine GNA sur des larves d'abeilles élevées in vitro.

Apis mellifera / Bacillus thuringiensis / évaluation du risque environnemental / culture génétiquement modifiée / protéine CRY

Effekte multipler Bt-Toxine und GNA-Lektin auf in vitro gezüchtete Larven der Honigbiene.

Apis mellifera / Bacillus thuringiensis / Umweltverträglichkeitsprüfung / Gentechnisch Veränderte Organismen / Cry-Protein

\section{REFERENCES}

Andersen, M.E., Dennison, J.E. (2004) Mechanistic approaches for mixture risk assessments-present capabilities with simple mixtures and future directions. Environ. Toxicol. Pharmacol. 16, 1-11

Arpaia, S. (1996) Ecological impact of Bt-transgenic plants: 1 Assessing possible effects of CryIIIB toxin on honey bee (Apis mellifera L) colonies. J. Genet. Breed. 50, 315-319

Aupinel, P., Fortini, D., Michaud, B., Marolleau, F., Tasei, J.N., Odoux, J.F. (2007) Toxicity of dimeth- 
oate and fenoxycarb to honey bee brood (Apis mellifera), using a new in vitro standardized feeding method. Pest Manage Sci. 63, 1090-1094

Babendreier, D., Kalberer, N., Romeis, J., Fluri, P., Bigler, F. (2004) Pollen consumption in honey bee larvae: a step forward in the risk assessment of transgenic plants. Apidologie 35, 293-300

Babendreier, D., Kalberer, N.M., Romeis, J., Fluri, P., Mulligan, E., Bigler, F. (2005) Influence of Bttransgenic pollen, Bt-toxin and protease inhibitor (SBTI) ingestion on development of the hypopharyngeal glands in honeybees. Apidologie 36, 585-594

Babendreier, D., Reichhart, B., Romeis, J., Bigler, F. (2008) Impact of insecticidal proteins expressed in transgenic plants on bumblebee microcolonies. Entomol. Exp. Appl. 126, 148-157

Belzunces, L.P., Lenfant, C., Di Pasquale, S., Colin, M. E. (1994) In vivo and in vitro effects of wheat germ agglutinin and Bowman-Birk soybean trypsin inhibitor, two potential transgene products, on midgut esterase and protease activities from Apis mellifera. Comp. Biochem. Physiol. 109, 63-69

Chambers J.M. (1992) Linear models. Chapter 4 of Statistical Models in S eds. J.M. Chambers, T.J. Hastie, Wadsworth \& Brooks/Cole.

Cox D.R., Oakes D. (1990) Analysis of survival data London: Chapman \& Hall 201 p.

Crailsheim, K., Schneider, L.H.W., Hrasnigg, N., Bühlmann, G., Brosch, U., Gmeinbauer, R., Schöffmann, B. (1992) Pollen consumption and utilization in worker honeybees (Apis mellifera carnica): dependence on individual age and function. J. Insect Physiol. 38, 409-419

De Maagd, R.A., Bravo, A., Crickmore, N. (2001) How Bacillus thuringiensis has evolved specific toxins to colonize the insect world. Trends Genet. 17, 193-199

Duan, J.J., Marvier, M., Huesing, J., Dively, G., Huang, Z.Y. (2008) A Meta-Analysis of Effects of Bt Crops on Honey Bees (Hymenoptera: Apidae). PLoS One 3, e1415

Duan, J.J., Lundgren, J.G., Naranjo, S., Marvier, M. (2010) Extrapolating non-target risk of Bt crops from laboratory to field. Biol. Lett. 6, 74-77

European Food Safety Authority (2010) Scientific opinion on application (EFSA-GMO-NL-2007-39) for the placing on the market of insect resistant and herbicide tolerant genetically modified maize MON89034× MON88017 for food and feed uses, import and processing under Regulation (EC) No 1829/2003 from Monsanto, EFSA Journal, 8, Article 1564

Finney, D.J. (1971) Probit Analysis. Cambridge University Press Cambridge, UK

Fox, J. (2002) An R and S-PLUS companion to applied regression. Sage, Thousand Oaks, CA. 312 p

Glare, T.R., O'Callaghan, M. (2000) Bacillus thuringiensis: Biology, Ecology and Safety. John Wiley and Sons Ltd, Chichester, UK
Hanley, A.V., Huang, Z.Y., Pett, W.L. (2003) Effects of dietary transgenic Bt corn pollen on larvae of Apis mellifera and Galleria mellonella. J. Apic. Res. 42, 77-81

Hendriksma, H.P., Härtel, S., Steffan-Dewenter, I. (2011a) Honey bee risk assessment: New approaches for in vitro larvae rearing and data analyses. Meth. Ecol. Evol. 2, 509-517

Hendriksma, H.P., Härtel, S., Steffan-Dewenter, I. (2011b) Testing pollen of single and stacked insect-resistant Bt-maize on in vitro reared honey bee larvae. PLoS One 6, e28174. doi:10.1371/journal.pone.0028174

Jaber K., Haubruge E., Francis F. (2010) Development of entomotoxic molecules as control agents: illustration of some protein potential uses and limits of lectins (Review), Biotech. Agron. Soc. Environ.14, 225-241.

James C. (2010) Global Status of Commercialized Biotech/GM Crops: 2009 ISAAA Brief No 42 ISAAA: Ithaca, NY.

Jung-Hoffmann, I. (1966) Die Determination von Königin und Arbeiterin der Honigbiene. Z. Bienenforsch. 8, 296-322

Khasdan, V., Sapojnik, M., Zaritsky, A., Horowitz, A.R., Boussiba, S., Rippa, M., Manasherob, R., Ben-Dov, E. (2007) Larvicidal activities against agricultural pests of transgenic Escherichia coli expressing combinations of four genes from Bacillus thuringiensis. Arch. Microbiol. 188, 643-653

Klein, A.M., Vaissiere, B.E., Cane, J.H., SteffanDewenter, I., Cunningham, S.A., Kremen, C., Tscharntke, T. (2007) Importance of pollinators in changing landscapes for world crops. Proc. R. Soc. London 274, 303-313

Konrad, R., Ferry, N., Gatehouse, A.M.R., Babendreier, D. (2008) Potential Effects of Oilseed Rape Expressing Oryzacystatin-1 (OC-1) and of Purified Insecticidal Proteins on Larvae of the Solitary Bee Osmia bicornis. PLoS One 3, e2664

Lee, M.K., Curtiss, A., Alcantara, E., Dean, D.H. (1996) Synergistic Effect of the Bacillus thuringiensis Toxins CryIAa and CryIAc on the Gypsy Moth, Lymantria dispar. Appl. Environ. Microbiol. 62, 583-586

Lehrman, A. (2007) Does pea lectin expressed transgenically in oilseed rape (Brassica napus) influence honey bee (Apis mellifera) larvae? Environ. Biosaf. Res. 6, 271-278

Lima, M.A.P., Pires, C.S.S., Guedes, R.N.C., Nakasu, E. Y.T., Lara, M.S., Fontes, E.M.G., Sujii, E.R., Dias, S.C., Campos, L.A.O. (2011) Does Cry1Ac Bt-toxin impair development of worker larvae of Africanized honey bee? J. Appl. Entomol. 135, 415-422

Malone L.A., Burgess E.P.J. (2009) Impact of Genetically Modified Crops on Pollinators. pp 199-224 in: Environmental Impact of Genetically Modified 
Crops Eds. N. Ferry, A.M.R. Gatehouse, CAB International, Oxfordshire, UK.

Monsanto Company (2009) Application for authorization of MON89034×MON88017 maize in the European Union, according to Regulation (EC) No 1829/2003 on genetically modified food and feed, Accessed $11 \mathrm{Mar}$ 2011: www.gmo-compassorg/pdf/regulation/maize/ MON89034xMON88017_applicationpdf.

Niu, G.D., Johnson, R.M., Berenbaum, M.R. (2011) Toxicity of mycotoxins to honeybees and its amelioration by propolis. Apidologie 42, 79-87

Padgette, S.R., Kolacz, K.H., Delannay, X., Re, D.B., La Vallee, B.J., Tinius, C.N., Rhodes, W.K., Otero, Y.I., Barry, G.F., Eichholz, D.A., Peschke, V.M., Nida, D. L., Taylor, N.B., Kishore, G.M. (1995) Development, identification and characterization of a glyphosatetolerant soybean line. Crop Sci. 35, 1451-1461

Pardo-López, L., Muñoz-Garay, C., Porta, H., RodríguezAlmazán, C., Soberón, M., Bravo, A. (2009) Strategies to improve the insecticidal activity of Cry toxins from Bacillus thuringiensis. Pept. 30, 589-595

Peterson, R.K., Shama, L.M. (2005) A comparative risk assessment of genetically engineered, mutagenic, and conventional wheat production systems. Transgenic Res. 14, 859-875

Peumans, W.J., Smeets, K., Van Nerum, K., Van Leuven, F., Van Damme, E.J.M. (1997) Lectin and alliinase are the predominant proteins in nectar from leek (Allium porrum L) flowers. Planta 201, 298-302

Pigott, C.R., King, S.M., Ellar, D.J. (2008) Investigating the properties of Bacillus thuringiensis Cry-proteins with novel loop replacements created using combinatorial molecular biology. Appl. Environ. Microbiol. 74, 3497-3511

Porcar, M., Gomez, F., Gruppe, A., Gomez-Pajuelo, A., Segura, I., Schroder, R. (2008) Hymenopteran specificity of Bacillus thuringiensis strain PS86Q3. Biol Control 45, 427-432

Potts, S.G., Biesmeijer, J.C., Kremen, C., Neumann, P., Schweiger, O., Kunin, W.E. (2010) Global pollinator declines: trends, impacts and drivers. Trends Ecol. Evol. 25, 345-353

R Development Core Team (2010). R: A language and environment for statistical computing. R Foundation for Statistical Computing, Vienna, Austria. http:// www.R-project.org.

Romeis, J., Babendreier, D., Wackers, F.L. (2003) Consumption of snowdrop lectin (Galanthus nivalis agglutinin) causes direct effects on adult parasitic wasps. Oecologia 134, 528-536
Romeis, J., Bartsch, D., Bigler, F., Candolfi, M.P., Gielkens, M.M.C., Hartley, S.E., Hellmich, R.L., Huesing, J.E., Jepson, P.C., Layton, R., Quemada, H., Raybould, A., Rose, R.I., Schiemann, J., Sears, M.K., Shelton, A.M., Sweet, J., Vaituzis, Z., Wolt, J. D. (2008) Assessment of risk of insect-resistant transgenic crops to nontarget arthropods. Nat. Biotechnol. 26, 203-208

Romeis, J., Hellmich, R.L., Candolfi, M.P., Carstens, K., De Schrijver, A., Gatehouse, A.M., Herman, R.A., Huesing, J.E., McLean, M.A., Raybould, A., Shelton, A.M., Waggoner, A. (2011) Recommendations for the design of laboratory studies on arthropods for risk assessment of genetically engineered plants. Transgenic Res. 20, 1-22

Romeis, J., Meissle, M., Bigler, F. (2006) Transgenic crops expressing Bacillus thuringiensis toxins and biological control. Nat. Biotechnol. 24, 63-71

Seeley, T.D. (1985) Honey bee ecology. Princeton University Press, New Jersey

Sharma, P., Nain, V., Lakhanpaul, S., Kumar, P.A. (2010) Synergistic activity between Bacillus thuringiensis toxins against maize stem borer (Chilo partellus Swinhoe). Lett. Appl. Microbiol. 51, 42-47

Simpson, J. (1955) The significance of the presence of pollen in the food of worker larvae of the honey-bee. Quart. J. Microscop. Sci. 96, 117-120

Steinrücken, H.C., Amrhein, N. (1980) The herbicide glyphosate is a potent inhibitor of 5-enolpyruvylshikimic acid-3-phosphate synthase. Biochem. Biophys. Res. Commun. 94, 1207-1212

Stewart, S.D., Adamczyk, J.J., Knighten, K.S., Davis, F. M. (2001) Impact of Bt cottons expressing one or two insecticidal proteins of Bacillus thuringiensis Berliner on growth and survival of noctuid (Lepidoptera) larvae. J. Econ. Entomol. 94, 752-760

Wolt, J.D. (2011) A mixture toxicity approach for environmental risk assessment of multiple insect resistance genes. Environ. Toxicol. Chem. 30, 1-10

Yao, H.W., Jiang, C.Y., Ye, G.Y., Hu, C., Peng, Y.F. (2008) Toxicological assessment of pollen from different Bt rice lines on Bombyx mori (Lepidoptera: Bombyxidae). Environ. Entomol. 37, 825-837

Zuur A.F., Gende L.B., Ieno E.N., Fernandez N.J., Eguares M.J., Fritz R., Walker N.J., Saveliev A.A., Smith G.M. (2009) Mixed Effects Modelling Applied on American Foulbrood Affecting Honey Bees Larvae. Mixed effects models and extensions in ecology with R (eds A.F. Zuur, E.N. Ieno, N.J. Walker, A.A. Saveliev, G.M. Smith), pp. 447-458. Springer Science+Business Media, New York. 